\title{
Development of Monoclonal Antibodies that Specifically React with a Fish Pathogen, Vibrio anguillarum serotype J-O-1
}

\author{
Nobukazu Miyamoto and Mitsuru Eguchi ${ }^{\dagger}$ \\ Department of Fisheries, Faculty of Agriculture, Kinki University, Nakamachi, Nara 631, Japan \\ (Received December 18, 1995)
}

\begin{abstract}
Five monoclonal antibodies (MAbs) against cell surface antigens of Vibrio anguillarum serotype JO-1 were developed by a hybridoma technique. Three of the MAbs, VA19-1, VA19-2, and VA19-4, reacted only with serotype J-O-1. The remaining two MAbs, VA07-1 and VA07-2, showed cross-reaction with some other Vibrio species. MAbs VA19-1, VA19-2, and VA19-4 could react with heat treated $\left(100^{\circ} \mathrm{C}\right.$ for $\left.1 \mathrm{~h}\right)$ cells of $V$. anguillarum $\mathrm{J}-\mathrm{O}-1$. This indicated that the antigens recognized by these MAbs were stable molecules such as lipopolysaccharide. As almost all strains of $V$. anguillarum isolated from diseased ayu Plecoglossus altivelis in freshwater belong to serotype J-O-1, MAbs VA19-1, VA19-2, and VA19-4 are useful for rapid identification and direct detection of $V$. anguillarum J-O- 1 in natural freshwater environments. Furthermore, MAbs VA19-1, VA19-2, and VA19-4 specifically reacted with $V$. anguillarum serotype $\mathrm{O} 2$ among ten Danish serotypes $(\mathrm{O} 1 \sim \mathrm{O} 10)$ and did not react with $V$. ordalii. Thus, these MAbs are also useful for distinction between closely related species, $V$. anguillarum $\mathrm{O} 2$ and $V$. ordalii.
\end{abstract}

Key words: Vibrio anguillarum, serotype $\mathrm{J}-\mathrm{O}-1$, ayu Plecoglossus altivelis, vibriosis, monoclonal antibody

In the early summer of 1989 , more than 4 million individual fish of wild ayu Plecoglossus altivelis (Salmoniforms: Plecoglossidae) died due to vibriosis in Lake Biwa, Japan. In July 1990, more than 1.6 million individual fish of wild ayu were killed by the same disease. Although such mass killings of wild ayu in early summer have been reported since 1983, the cases of 1989 and 1990 were marked by the huge number of deaths. ${ }^{1)}$ The causative agent of ayu vibriosis in Lake Biwa is usually Vibrio anguillarum ${ }^{1)}$ and almost all of them belong to serotype $\mathrm{J}-\mathrm{O}-{ }^{2}{ }^{2)}$

Vibriosis caused by $V$. anguillarum $\mathrm{J}-\mathrm{O}-1$ occurs almost every year in Lake Biwa. However, the pathogen of this serotype has not been detected from the freshwater environment by a conventional cultural method, ${ }^{3)}$ because of losing culturability under the freshwater environment. ${ }^{3-5)}$ Therefore, as far as the conventional cultural method is used, it seems to be impossible for us to detect the pathogen from freshwater environments. From a commercial point of view, ayu is one of the most important species among freshwater fishes in Japan. Thus, it is urgent to make clear the infectious process of vibriosis in ayu under freshwater environments.

The indirect immunofluorescence assay using polyclonal antisera may be useful and easier for detecting a nonculturable pathogen. ${ }^{6}$ However, the use of polyclonal antisera has some problems. Polyclonal antisera raised in animals are variable in both quality and quantity. ${ }^{7}$ The antisera often show the high cross-reactivities. For example, $V$. anguillarum shared antigens with other Vibrio species, as well as with Aeromonas and Pseudomonas species. ${ }^{8)}$ In contrast to antisera, although it takes longer time to get specific monoclonal antibodies (MAbs), highly specific
MAbs are expected to solve those problems which polyclonal antisera have. ${ }^{7)}$ When both polyclonal rabbit antiserum and MAb against Vibrio salmonicida was used to detect this pathogen in fish farm sediments, the number of positive samples by polyclonal rabbit antiserum was about eight times higher than that of MAbs.")

In the present study, we developed highly specific MAbs for $V$. anguillarum $\mathrm{J}-\mathrm{O}-1$. We checked the cross-reactivities of our MAbs with not only eight Japanese serotypes (J-O-1 $\sim \mathrm{J}-\mathrm{O}-8)$ of $V$. anguillarum but also ten Danish serotypes $(\mathrm{O} 1 \sim \mathrm{O} 10){ }^{10)}$

\section{Materials and Methods}

\section{Bacterial Strains}

Vibrio anguillarum J-O-1 strains, psh-9019 and psh9007, isolated from diseased ayu in Lake Biwa, were used for the development of MAbs. Other strains listed in Tables 1 and 2 were used for cross-screening of MAbs.

\section{Preparation of Antigens and Immunization Protocols}

Cells of $V$. anguillarum psh-9019 or 9007 grown in brain heart infusion broth (Difco) with $2.0 \% \mathrm{NaCl}$ at $20^{\circ} \mathrm{C}$ were centrifuged at $7,500 \times g\left(20^{\circ} \mathrm{C}\right.$ for $\left.5 \mathrm{~min}\right)$ and washed three times with phosphate-buffered saline (PBS, $\mathrm{pH}$ 7.2). The final pellet was resuspended in PBS. The cell density in PBS was $2 \times 10^{7}$ cells $/ \mathrm{m} l$. This cell suspension was used as an antigen.

Six week-old female BALB/c mice were injected intraperitoneally with $0.5 \mathrm{~m} l$ of the cell suspension $\left(2 \times 10^{7}\right.$ cells $/ \mathrm{ml}$ ) once a week for six weeks. After the last injection, the mice were boosted with $10^{8}$ cells of $V$. anguilla-

\footnotetext{
${ }^{\dagger}$ Corresponding author.
} 
Table 1. Reactivities of five monoclonal antibodies with strains of Vibrio species by indirect immunofluorescence assay

\begin{tabular}{|c|c|c|c|c|c|c|}
\hline \multirow{2}{*}{ Vibrio species } & \multirow{2}{*}{ Strain (serotype) } & \multicolumn{5}{|c|}{ Reactivities of monoclonal antibodies: } \\
\hline & & VA07-1 & VA07-2 & VA19-1 & VA19-2 & VA19-4 \\
\hline \multirow[t]{11}{*}{$V$. anguillarum } & psh-9007(J-O-1) & $+t+$ & +++ & $++t$ & +++ & +++ \\
\hline & psh-9019(J-O-1) & +++ & +++ & +++ & +++ & +++ \\
\hline & $\mathrm{sgv}-9001(\mathrm{~J}-\mathrm{O}-1)$ & +++ & ++ & +++ & $+t+$ & ++ \\
\hline & $\mathrm{V}-7(\mathrm{~J}-\mathrm{O}-1)$ & +++ & $+t+$ & +++ & +++ & +++ \\
\hline & $\mathrm{V}-123(\mathrm{~J}-\mathrm{O}-2)$ & ++ & + & - & - & - \\
\hline & $\mathrm{V}-104(\mathrm{~J}-\mathrm{O}-3)$ & \pm & \pm & - & - & - \\
\hline & $V-183(J-O-4)$ & + & + & - & - & - \\
\hline & $\mathrm{V}-196(\mathrm{~J}-\mathrm{O}-5)$ & ++ & ++ & - & - & - \\
\hline & $V-231(J-O-6)$ & ++ & ++ & - & - & - \\
\hline & $\mathrm{V}-116(\mathrm{~J}-\mathrm{O}-7)$ & +++ & +++ & - & - & - \\
\hline & E6-5(J-O-8) & \pm & \pm & - & - & - \\
\hline V. campbellii & ATTC 25920 & \pm & + & - & - & - \\
\hline V. carchariae & ATCC 35084 & ++ & $+t$ & - & - & - \\
\hline$V$. damsela & ATCC 33539 & \pm & + & - & - & - \\
\hline V. fischeri & ATCC 7744 & ++ & $+t$ & - & - & - \\
\hline V. fluvialis & NCTC 11327 & $+t$ & ++ & - & - & - \\
\hline V. harveyi & ATCC 14126 & - & - & - & - & - \\
\hline V. logei & ATCC 15382 & - & - & - & - & - \\
\hline V. mediterranei & ATCC 43341 & - & - & - & - & - \\
\hline V. mimicus & ATCC 33653 & - & - & - & - & - \\
\hline V. natriegens & CCM 2575 & - & - & - & - & - \\
\hline V. nereis & ATCC 25917 & - & - & - & - & - \\
\hline$V$. ordalii & ATCC 33509 & $+t$ & ++ & - & - & - \\
\hline V. parahaemolyticus & IFO 12711 & - & - & - & - & - \\
\hline$V \cdot$ pelagius & ATCC 25916 & ++ & ++ & - & - & - \\
\hline V. proteolyticus & NCMB 1326 & +++ & +++ & - & - & - \\
\hline V. splendidus & ATCC 33125 & - & - & - & - & - \\
\hline
\end{tabular}

+++ , positive cell ratio $80-100 \% ;++, 50-80 \% ;+, 30-50 \% ; \pm, 10-30 \% ;-, 0 \%$.

Table 2. Reactivities of five monoclonal antibodies with ten Danish serotypes of Vibrio anguillarum by indirect immunofluorescence assay

\begin{tabular}{|c|c|c|c|c|c|c|}
\hline \multirow{2}{*}{$\begin{array}{l}\text { Danish } \\
\text { serotype }\end{array}$} & \multirow{2}{*}{ Strain } & \multicolumn{5}{|c|}{ Reactivities of monoclonal antibodies: } \\
\hline & & VA07-1 & VA07-2 & VA19-1 & VA19-2 & VA19-4 \\
\hline 01 & ATCC 43305 & + & + & - & - & - \\
\hline $\mathrm{O} 2$ & ATCC 43306 & +++ & +++ & $+t+$ & +++ & $+t+$ \\
\hline 03 & ATCC 43307 & + & $+t$ & - & - & - \\
\hline 04 & ATCC 43308 & - & + & - & - & - \\
\hline O5 & ATCC 43309 & + & + & - & - & - \\
\hline 06 & ATCC 43310 & + & + & - & - & - \\
\hline 07 & ATCC 43311 & + & \pm & - & - & - \\
\hline 08 & ATCC 43312 & + & + & - & - & - \\
\hline 09 & ATCC 43313 & \pm & \pm & - & - & - \\
\hline 010 & ATCC 43314 & + & + & - & - & - \\
\hline
\end{tabular}

+++ , positive cell ratio $80-100 \% ;++, 50-80 \% ;+, 30-50 \% ; \pm, 10-30 \% ;-$ $0 \%$

rum J-O-1.

\section{Hybridoma Production}

Three days after the booster injection, the spleens of the immunized mice were removed under sterile conditions. Murine myeloma cells (P3X63-Ag8.653) were grown in RPMI 1640 medium (Nissui seiyaku) containing penicillin $(100 \mathrm{IU} / \mathrm{m} l)$, streptomycin $(100 \mu \mathrm{g} / \mathrm{m} l)$, and $10 \%$ of Daigo's GF21 (Nihon seiyaku) instead of fetal cow serum as a growth promoter in a tissue culture incubator at $37^{\circ} \mathrm{C}$ with $5 \% \mathrm{CO}_{2}$ and $95 \%$ air. Myeloma cells were mixed with the spleen cells at a ratio of $1: 10$. One $\mathrm{m} l$ of $0.22 \mu \mathrm{m}$-filter sterilized $50 \%$ polyethylene glycol \#3350 (Sigma) was slowly added to the cell mixture with gentle stirring for 1 min. The fused cells were gently washed with RPMI 1640 medium, resuspended in RPMI 1640 medium containing $10 \%$ Daigo's GF21, and dispensed into 96-well microtiter plates (Corning). After overnight incubation at $37^{\circ} \mathrm{C}$ with $5 \% \mathrm{CO}_{2}$ and $95 \%$ air, RPMI 1640 medium containing $10 \%$ Daigo's GF21, hypoxanthine, aminopterin, and thymidine (HAT medium) was added to each well, then the plates were incubated continually. After ten days of the cell fusion, the HAT medium was replaced with HAT medium without aminopterin (HT medium), and then with RPMI 1640 medium containing $10 \%$ of Daigo's GF21.

\section{ELISA for Screening Hybridomas}

Culture supernatants of the hybridomas were screened against homologous bacterial strains by enzyme-linked immunosorbent assay (ELISA), ${ }^{1)}$ using peroxidase conjugated goat anti-mouse $\operatorname{Ig}(\mathrm{G}+\mathrm{A}+\mathrm{M}$ ) (Cappel) and 2,2'azino-di-3-ethylbenzothiazoline sulfonate (Cappel). The optical density of each well was read at $405 \mathrm{~nm}$ with a microplate reader (Bio-Rad, Model 1450). The supernatant of myeloma cells and the antisera of immunized mice were used as negative and positive controls, respectively.

\section{Cloning}

Clonings of hybridoma cells which produced MAbs in 
each well of microtiter plates were carried out at least twice by an extinction dilution method ${ }^{12)}$ with mitomycin $C$ treated spleen cells of non-immunized mice (feeder cells; $1 \times 10^{6}$ cells $/$ well). Clones were multiplied gradually in RPMI 1640 medium containing 10\% Daigo's GF21. The culture supernatants containing the MAbs were obtained by centrifugation.

Immunogloburin classes and sub-classes of MAbs were determined by a Mouse Mono Ab-ID kit (Zymed).

\section{Indirect Immunofluorescence Assay for Determining the Specificities of $M A b s$}

MAbs were rescreened against a wide range of Vibrio species and other gram-negative bacterial strains to determine their specificities. Indirect immunofluorescence assay was carried out by a double staining method. ${ }^{13)}$ Bacterial cells fixed in $2 \%$ (vol/vol) formaldehyde were stained with fluorochrome $4^{\prime}, 6$-diamidino-2-phenylindole (DAPI; 0.5 $\mu \mathrm{g} / \mathrm{m} l$ in final conc.) and filtered onto $0.2 \mu \mathrm{m}$ pore size black membrane filters ( $\varnothing 25 \mathrm{~mm}$; Nuclepore). The filters were washed three times with $5 \mathrm{~m} l$ PBS containing $0.05 \%$ tween 20 (PBS-tween). Then, the filters were covered with $1 \mathrm{ml}$ of the culture supernatants of hybridomas producing MAbs. After $30 \mathrm{~min}$ incubation at $37^{\circ} \mathrm{C}$, the supernatants were removed, and the filters were washed five times with PBS-tween. Finally, the filters were treated with fluorescein isothiocyanate (FITC) labeled goat anti-mouse $\mathrm{Ig}$ $(\mathrm{G}+\mathrm{M}+\mathrm{A})$ conjugate (Cappel) which was diluted 100 times with PBS-tween containing $2 \%$ bovine serum albu$\min (\mathrm{BSA})$. After the filters were incubated at $37^{\circ} \mathrm{C}$ for 30 $\mathrm{min}$, they were washed five times. The filters were placed onto slides and coverslips were applied with one drop of non-fluorescence glycerol. The slides were observed at $1,000 \mathrm{X}$ with an epifluorescence microscope (Olympus). FITC-stained cells (Fig. 2B and D) were counted under blue excitation (positive counts) and DAPI-stained cells (Fig. 2A and C) in the same field were counted under UV excitation (total counts) at the same time. The reactivity of $\mathrm{MAb}$ was evaluated by a ratio of the positive counts to the total counts.

The MAbs were also checked whether they reacted with cells of psh- 9019 heated at $100^{\circ} \mathrm{C}$ for $1 \mathrm{~h}$. The reactivity was tested by indirect immunofluorescence assay described above.

\section{Electrophoresis and Immunoblot Analyses for Determin- ing the Antigens}

SDS polyacrylamide gel electrophoresis (SDS-PAGE) was performed with $12.5 \%$ slab gels as described by Laemmli. ${ }^{14)}$ Samples of bacterial whole proteins were diluted in a sample buffer and 5.0 to $7.5 \mu \mathrm{g}$ proteins per lane were separated on SDS-PAGE at $20 \mathrm{~mA} / \mathrm{gel}$ at room temperature. The separated components were visualized by coomassie brilliant blue staining. Additional gels were run, and the separated components were transferred to nitrocellulose membranes (Bio-Rad) by Western blotting. ${ }^{15)}$ The transfer was carried out at $2.0 \mathrm{~mA} / \mathrm{cm}^{2}$ for $1 \mathrm{~h}$ at room temperature. Prestained low-molecular-weight standards (Bio-Rad) were used to monitor separations and transfers and the non-stained standards were used to assess molecular weights.

Immunostaining protocol by Smith et al. ${ }^{16)}$ was followed with some modifications. After Western blotting, the membrane was blocked with PBS-tween containing 3\% BSA at $4^{\circ} \mathrm{C}$ overnight and washed three times with PBS-tween. A $500 \mu l$ portion of the supernatant containing the MAb was dropped on a parafilm, covered with the membrane, and incubated at $37^{\circ} \mathrm{C}$ for $30 \mathrm{~min}$. After washing three times, the membrane was incubated with $500 \mu l$ of peroxidase conjugated goat anti-mouse $\operatorname{Ig}(\mathrm{G}+\mathrm{A}+\mathrm{M}$ ) (diluted 1:500 in PBS-tween containing $2 \% \mathrm{BSA}$ ) at $37^{\circ} \mathrm{C}$ for $30 \mathrm{~min}$ as described above and then washed three times. The membrane was soaked in a substrate solution of $0.1 \mathrm{M}$ Tris- $\mathrm{HCl}$ buffer (pH 7.4) containing 0.01\% 3,3'-diamino-benzidine tetrahydrochloride (Cappel) and $0.01 \% \mathrm{H}_{2} \mathrm{O}_{2}$. After visualization of bands, the membrane was washed with double distilled water, dried, and stored in the dark.

\section{Results}

\section{Production of MAbs}

Culture supernatants of the growing hybridoma colonies in HT medium were screened in ELISA to get positive clones which produced MAbs reacting with intact cells of homologous strains, $V$. anguillarum psh-9019 or psh-9007 (serotype J-O-1). Finally, five stable hybridomas were obtained. Three of them were derived from psh-9019, and two from psh-9007. These hybridomas and their corresponding MAbs were designated VA19-1, VA19-2, VA19. 4, VA07-1, and VA07-2. Isotypes of these MAbs were $\mathrm{IgG}_{3}, \operatorname{IgG}_{3}, \operatorname{IgG}_{2 \mathrm{~b}}, \operatorname{IgM}$, and IgM, respectively. Light chains were all $\kappa$.

\section{Cross-reactivities of $M A b s$}

The reactivities of these five MAbs with strains of Vibrio species are shown in Table 1. They were checked by indirect immunofluorescence assay. MAbs VA07-1 and VA07-2 strongly reacted with $V$. anguillarum $\mathrm{J}-\mathrm{O}-1$, however, they also showed cross-reactivities with other serotypes of $V$. anguillarum and some other Vibrio species, such as $V$. carchariae, $V$. fischeri, V. fluvialis, $V$. ordalii, $V$. pelagius, and $V$. proteolyticus (Table 1). On the other hand, MAbs VA19-1, VA19-2, and VA19-4 showed very high specificities for $\mathrm{J}-\mathrm{O}-1$ and did not react with other serotypes of $V$. anguillarum. These Three MAbs also strongly reacted with 36 strains of $V$. anguillarum $\mathrm{J}-\mathrm{O}-1$ isolated from dead ayu of Lake Biwa at various locations in different years.

All of the five MAbs did not react with non-Vibrio gram negative bacterial strains, such as Aeromonas caviae, $A$. hydrophila, A. salmonicida, Citrobacter freundii, Escherichia coli, Klebsiella pneumoniae, Photobacterium phosphoreum, Proteus vulgaris, Pseudomonas aeruginosa, Salmonella typhimurium, and Serratia marcescens. The reactivities of these MAbs were also tested with 50 unidentified bacterial strains isolated from Lake Biwa which showed different colony types (size, shape and color) on nutrient agar. None of the five MAbs reacted with these 50 unidentified isolates.

Furthermore, we examined the reactivities of these MAbs with ten Danish serotypes strains $(\mathrm{O} 1 \sim \mathrm{O} 10)$ of $V$. anguillarum by indirect immunofluorescence assay (Table 2). All MAbs strongly reacted with Danish serotype $\mathrm{O} 2$. MAbs VA07-1 and VA07-2 showed cross-reactivities with 


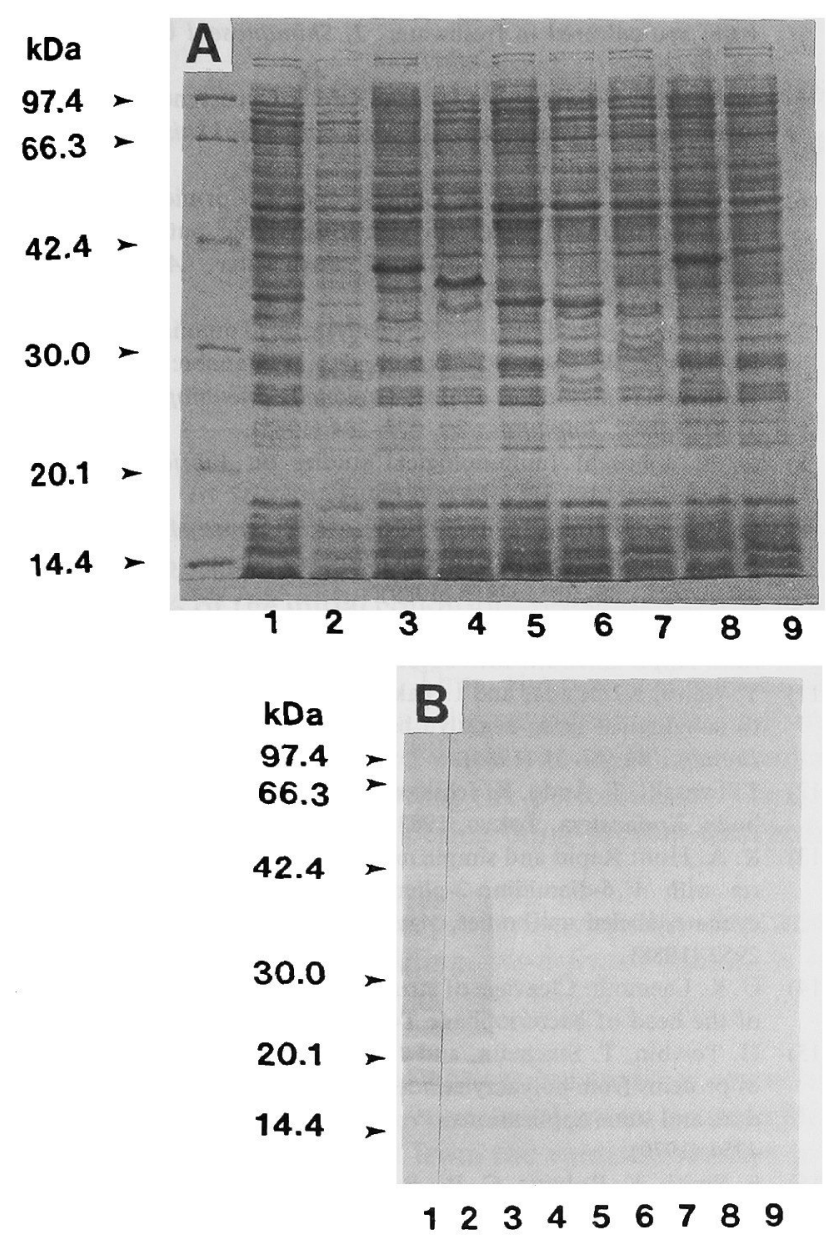

Fig. 1. (A) Whole protein band patterns of Vibrio anguillarum strains separated on SDS-PAGE with coomassie brilliant blue staining and (B) the Western blot of SDS-PAGE showing the antigens recognized by MAb VA19-1.

Lanes: 1, strain psh-9019 (serotype J-O-1); 2, V-7 (J-O-1); 3, V123 (J-O-2); 4, V-104 (J-O-3); 5, V-183 (J-O-4); 6, V-196 (J-O-5); 7 V-231 (J-O-6); 8, V-116 (J-O-7); 9, E6-5 (J-O-8).

some other Danish serotypes, however, MAbs VA19-1, VA19-2, and VA19-4 did not react with other Danish serotypes.

\section{Immunoblotting}

Cellular whole proteins of $V$. anguillarum serotypes $\mathrm{J}-$ O-1 to $\mathrm{J}-\mathrm{O}-8$ were analyzed on SDS-PAGE. They were transferred to a nitrocellulose membrane by Western blotting and stained with MAb VA19-1 (Fig. 1). Except for a slight difference of main bands with a molecular size between 30 and $40 \mathrm{kDa}$, eight different serotypes of $V$. anguillarum showed similar SDS-PAGE patterns (Fig. 1A). After immunostaining with MAb VA19-1, many bands with a molecular size between 17 and $38 \mathrm{kDa}$ appeared in the lanes of $V$. anguillarum J-O-1, psh-9019 and V-7 (Fig. 1B, lanes 1 and 2). MAb VA19-1 showed no cross-reaction with proteins originating from other serotypes (Fig. 1B, lanes 3 to 9). Antigens recognized by MAbs VA19-2, VA19-4, VA07-1, and VA07-2 were also analyzed in immunoblotting with homologous strains of $V$. anguillarum J-0-1. MAbs VA19-2 and VA19-4 showed similar im-

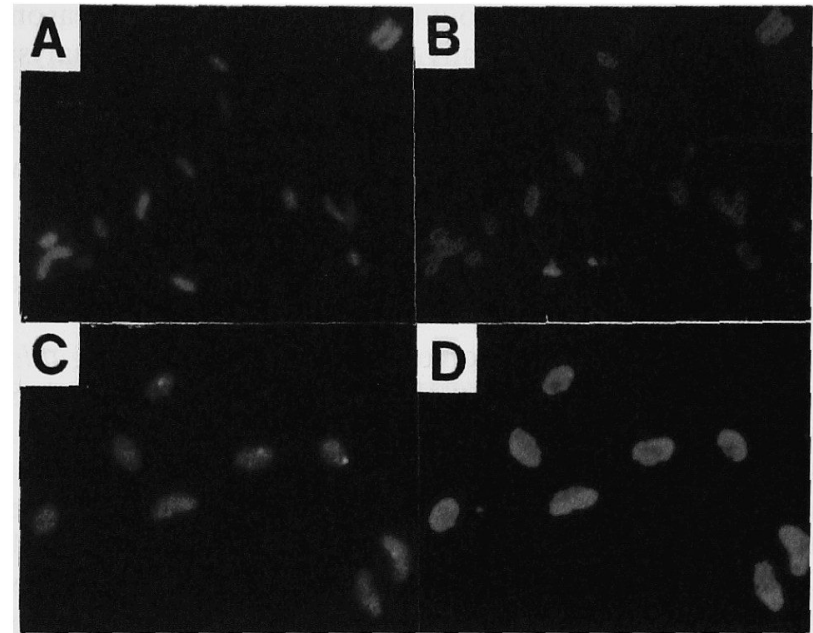

Fig. 2. Recognition of the cell surface antigens of Vibrio anguillarum psh-9019 (serotype J-O-1) by MAb VA19-1 with epifluorescence microscope under UV (A and C) and blue (B and D) excitations.

Panels: $A$ and $C$ are the same microscope fields as $B$ and D, respectively. A and B, the growing cells in BHI broth; C and D, the heat treated cells at $100^{\circ} \mathrm{C}$ for $1 \mathrm{~h}$.

munostained band patterns to those of MAb VA19-1 which were distributed between 17 and $38 \mathrm{kDa}$ in molecular size. On the other hand, immunostained bands visualized by MAbs VA07-1 and VA07-2, which were distributed between 15 and $38 \mathrm{kDa}$ in molecular size, were slightly different from those of MAbs VA19-1, VA19-2, and VA19-4 (data not shown).

We examined reactivities of MAb VA19-1 with heat treated $\left(100^{\circ} \mathrm{C}, 1 \mathrm{~h}\right)$ cells of $V$. anguillarum psh-9019 by a double staining method (Fig. 2). MAb VA19-1 strongly reacted with the surface antigens of the heated cells (Fig. 2D) as well as the growing cells (Fig. 2B). MAbs VA19-2 and VA19-4 could also strongly react with the heated cells (data not shown). MAbs VA07-1 and VA07-2 were not tested.

\section{Discussion}

There seems to be a relationship between the serological characteristics of $V$. anguillarum and geographical occurrences of vibriosis caused by this pathogen in Japan. Ezura et al. ${ }^{2)}$ reported that, in freshwater, almost all the strains of $V$. anguillarum isolated from dead fishes killed by vibriosis belonged to serotype $\mathrm{J}-\mathrm{O}-1$ and those in seawater to serotype J-O-3. Kitao et al. ${ }^{17)}$ reported that all 235 strains of $V$. anguillarum isolated from diseased ayu in Lake Biwa belonged to serotype A, which corresponded to serotype J-O-1. The indirect immunofluorescence assay indicated that three of the five MAbs developed in this study, MAbs VA19-1, VA19-2, and VA19-4, had high specificities for $V$. anguillarum J-O-1 (Table 1). We confirmed the same specificities of these MAbs in immunoblot analysis (Fig. 1B) and ELISA (data not shown).

In immunoblot analysis with homologous strains, there were many bands reacting with MAb VA19-1 (Fig. 1B). Nagasaki et al. ${ }^{18)}$ also reported similar findings in immunoblot analysis using MAbs against Chattonella mari- 
na. Campbell ${ }^{19)}$ pointed out that there were several reasons for the appearance of many bands in immunoblot analysis using MAbs after SDS-PAGE. In this case, the most reliable possibility was that epitopes recognized by the MAbs were on the antigens of various molecular sizes. ${ }^{18}$ ) As the antigenicity remained after heat treatment at $100^{\circ} \mathrm{C}$ for 1 $\mathrm{h}$, the antigens were stable molecules such as lipopolysaccharide on the outer membrane, but not unstable molecules, like proteins.

We used the designation of $\mathrm{O}$-serotyping of $\mathrm{V}$. anguillarum proposed by Ezura et al. , ${ }^{2)}$ serotypes J-O-1 to J-O-8, in this study. There are many reports dealing with the serology of $V$. anguillarum according to their heat stable $\mathrm{O}$-antigens. ${ }^{2,10,17,20)}$ Sørensen and Larsen ${ }^{10)}$ proposed ten serotypes (O1 O10) of $V$. anguillarum (ten Danish serotypes; Table 2) and discussed the correspondence of Danish serotype $\mathrm{O} 2$ to Japanese serotype $\mathrm{J}-\mathrm{O}-1$ by using a polyclonal antiserum. The MAbs, VA19-1, VA19-2, and VA19-4, specific for serotype J-O-1 showed high specificity for $V$. anguillarum $\mathrm{O} 2$ among ten Danish serotypes (Table 2). It was also supported in this study that Danish serotype $\mathrm{O} 2$ corresponded to the Japanese serotype J-O-1. Furthermore, the MAbs VA19-1, VA19-2, and VA19-4 specific for serotype J-O-1 did not react with $V$. ordalii (Table 1) which had been classified as $V$. anguillarum biotype $2 .{ }^{21)}$ MAbs against $V$. anguillarum $\mathrm{O} 2$ developed by Svendsen and Larsen ${ }^{22)}$ and MAbs against $V$. ordalii developed by Chen et al. ${ }^{23)}$ were found to cross-react with each other. MAbs against $V$. anguillarum $\mathrm{O} 2$ developed by Mutharia and $\mathrm{Amor}^{24)}$ showed no cross-reaction with $V$. ordalii, such as the MAbs developed in this study. However, their cross-reactivities with Japanese serotyping strains were not checked.

The MAbs specific for $V$, anguillarum $\mathrm{J}-\mathrm{O}-1$ which we developed in this study are useful not only for serological diagnostic purpose but also to elucidate the infectious process of vibriosis in a natural freshwater environment.

Acknowledgments We wish to thank Prof. A. Kawai of Kinki University for his continuous interest in this project. We also thank Prof. Y. Ezura and Dr. K. Tajima of Hokkaido University, Prof. K. Ohwada and Dr. K. Kita-Tsukamoto of Tokyo University, and the staff of the Shiga Prefectural Fisheries Experimental Station for providing the strains of $V$. anguillarum and other Vibrio species. This work was partly supported by funds granted by the Ministry of Education, Japan (Grant No. 07760194) and the Japan Private School Promotion Foundation. The first author is a research fellow of the Japan Society for the Promotion Science.

\section{References}

1) S. Satoi: Occurrence of vibriosis for ayu in Lake Biwa. Nippon Suisan Gakkaishi, 61, 942-943 (1995) (In Japanese).

2) Y. Ezura, K. Tajima, M. Yoshimizu, and T. Kimura: Studies on the taxonomy and serology of causative organisms of fish vibriosis. Fish Pathol., 14, 167-179 (1980) (In Japanese).

3) K. Muroga, M. Iida, H. Matsumoto, and T. Nakai: Detection of Vibrio anguillarum from waters. Bull. Japan. Soc. Sci. Fish., 52, 641-647 (1986).

4) T. Itami and R. Kusuda: Viability and pathogenicity of Vibrio anguillarum, in $\mathrm{NaCl}$ solutions of various concentrations, isolated from ayu cultured in freshwater. J. Shimonoseki Univ. Fish., 32, 33-39 (1984) (In Japanese).

5) M. Eguchi, N. Miyamoto, and A. Kawai: Occurrence of Vibrio anguillarum J-O-1 in the lake. Nippon Suisan Gakkaishi, 61, 944-945 (1995) (In Japanese).

6) C. Desmonts, J. Minet, R. Colwell, and M. Cormier: Fluorescentantibody method useful for detecting viable but nonculturable Salmonella spp. in chlorinated wastewater. Appl. Environ. Microbiol., 56, 1448-1452 (1990).

7) T. Miyazaki, H. Koga, M. Nakashima, A. Tomonaga, S. Kohno, M. Hirota, A. Saito, K. Hara, and T. Watanabe: Production of monoclonal antibodies against Legionella pneumophila serogroup 1. Microbiol. Immunol, 29, 275-284 (1985).

8) G. S. Johnsen: Immunological studies on Vibrio anguillarum. Aquaculture, 10, 221-230 (1977).

9) $\varnothing$. Enger, B. Husevåg, and J. Goksøyr: Presence of the fish patho gen Vibrio salmonicida in fish farm sediments. Appl. Environ. Microbiol., 55, 2815-2818 (1989).

10) U. B. S. Sørensen and J. L. Larsen: Serotyping of Vibrio anguillarum. Appl. Environ. Microbiol., 51, 593-597 (1986).

11) Y. Naito, K. Okuda, and I. Takazoe: Immunoglobulin G response to subgingival gram-negative bacteria in human subjects. Infect. Immun., 45, 47-51 (1984).

12) T. Iwasaki, T. Ando, K. Ichikawa, and K. Yasui: Monoclonal antibody, Kodanshya, Tokyo, 1983, pp. 73-85 (In Japanese).

13) K. A. Hoff: Rapid and simple method for double staining of bacteria with 4',6-diamidino-2-phenylindole and fluorescein isothiocyanate-labeled antibodies. Appl. Environ. Microbiol., 54, 2949 2952 (1988)

14) U. K. Laemmli: Cleavage of structural proteins during the assembly of the head of bacteriophage T4. Nature, 227, 680-685 (1970).

15) H. Towbin, T. Staehelin, and J. Gordon: Electrophoretic transfer of proteins from polyacrylamide gels to nitrocellulose sheets: Procedure and some applications. Proc. Natl. Acad. Sci. USA, 76, 43504354 (1979).

16) E. Smith, K. Roberts, G. W. Butcher, and G. Galfre: Monoclonal antibody screening: Two methods using antigens immobilized on nitrocellulose. Anal. Biochem., 138, 119-124 (1984).

17) T. Kitao, T. Aoki, M. Fukudome, K. Kawano, Y. Wada, and Y. Mizuno: Serotyping of Vibrio anguillarum isolated from diseased freshwater fish in Japan. J. Fish Dis., 6, 175-181 (1983).

18) K. Nagasaki, A. Uchida, S. Hiroishi, and Y. Ishida: An epitope recognized by the monoclonal antibody $M R-21$ which is reactive with the cell surface of Chattonella marina Type II. Nippon Suisan Gakkaishi, 57, 885-890 (1991).

19) A. M. Campbell: Monoclonal antibody technology (translated from English by T. Ohsawa), Tokyokagakudojin, Tokyo, 1989, pp. 191-205 (In Japanese).

20) R. Kusuda, K. Kawai, and H. Sako: Classification of vibrios isolated from diseased fishes-II. On the serological properties. Rep. Usa mar. biol. Inst., 3, 89-95 (1981) (In Japanese).

21) M. H. Schiewe, T. J. Trust, and J. H. Crosa: Vibrio ordalii sp. nov.: a causative agent of vibriosis in fish. Curr. Microbiol., 6, 343348 (1981).

22) I. Svendsen and J. L. Larsen: Monoclonal antibodies against surface antigens of Vibrio anguillarum serogroup $\mathrm{O} 2$. Acta Vet. Scand., 29, 363-368 (1988).

23) D. Chen, P. J. Hanna, K. Altmann, A. Smith, P. Moon, and L. S. Hammond: Development of monoclonal antibodies that identify Vibrio species commonly isolated from infections of humans, fish, and shellfish. Appl. Environ. Microbiol, 58, 3694-3700 (1992).

24) L. M. Mutharia and P. A. Amor: Monoclonal antibodies against Vibrio anguillarum $\mathrm{O} 2$ and Vibrio ordalii identify antigenic differences in lipopolysaccharide O-antigens. FEMS Microbiol. Lett., 123, 289-298 (1994). 